\title{
Grunnleggende kurs - bare for viderekomne?
}

Kravet om obligatoriske kurs går på bekostning av unge kirurgers læring og tvinger mer erfarne assistentleger på skolebenken av ren formalitet.

For å bli spesialist i generell kirurgi kreves 210 timer med kurs. 160 er obligatoriske (1). Et av disse er Basic surgical skills course (basal kirurgisk teknikk), basert på pensum av Royal College of Surgeons. Det avholdes ved St. Olavs hospital, Oslo universitetssykehus og Universitetssykehuset Nord-Norge 1-2 ganger i året med 15-16 deltagere per kurs. Man lærer blant annet hudsutur, ligaturer og abscessdrenasje. 15 minutter er satt av for introduksjon til skopisk kirurgi. 20 minutter er satt av til «påkledning av frakk og hansker». (2) Til årets første kurs var det 80 påmeldte i Oslo og 43 i Trondheim, med grenser på henholdsvis 31 og 16 måneders ansiennitet for å få være med, ifølge en e-post jeg fikk fra Kontor for legers videre- og etterutdanning i Oslo i november 2015.

Tanken bak obligatoriske kurs må være å standardisere utdanningen norske kirurger skal igjennom. Det er en god hensikt. Jeg vil påstå at leger i spesialisering i kirurgi med 31 måneders erfaring allerede skal vite hvordan man syr, knyter og tar på seg sterile hansker, og derfor ikke har noe på et slikt kurs å gjøre. Er man ikke introdusert for laparoskopisk kirurgi innen den tid, må man anta at sykehuset gjør svært mange laparotomier. De fleste har formodentlig etter $1 \frac{1 / 2}{2} 3$ år tilegnet seg de ferdigheter som undervises på dette kurset. Det som er ment som et basalkurs, blir i så fall praktisk talt en sertifiseringsprøve av to dagers varighet.

\section{Basale ferdigheter tidlig i løpet}

At de ferskeste leger i spesialisering i kirurgi prioriteres for disse kursene er vel det mest fornuftige? Riktig teknikk fra begynnelsen av vil gi raskere progresjon. Man vil tidligere kunne lære seg grunnleggende inn-

\section{«Riktig teknikk fra begynnelsen av vil gi raskere progresjon»}

grep og bli en ressurs for sykehuset. I dag er det liten grad av systematikk i opplæring av basale ferdigheter. Jeg tror dette hemmer effektiviteten når det gjelder å utdanne gode kirurger ved norske sykehus.

Strukturen i spesialiseringsløpet i kirurgi i Norge er i forandring. Kanskje er dette problemet allerede adressert? Man kan håpe. Om ikke, vil jeg foreslå følgende: Nyregistrering som lege i spesialisering i kirurgi bør føre til automatisk påmelding til et basalt ferdighetskurs, avholdt så tidlig som mulig i utdanningsløpet og ideelt sett innen de første tre månedene. Har man mer enn 1-2 år med erfaring bør det obligatoriske kravet frafalle dersom veileder mener kurset er overflødig. Det bør arrangeres flere kurs for å øke kapasiteten. Det bør være anledning til å ta kurset utenlands. Dette burde kom- penseres på lik linje med kurs tatt i Norge, forutsatt at kostnadene ikke er vesentlig høyere.

Vi ses på kurs, pleier man å skrive. Ikke med det første, skriver jeg. I mellomtiden får jeg sy sammen en banan. Stingene skal sitte.

\section{Stian Wendelborg}

stian.post@gmail.com

Stian Wendelborg (f. 1986) er lege i spesialisering i kirurgi ved Nordlandssykehuset. Forfatter har fylt ut ICMJE-skjemaet og oppgir ingen interessekonflikter.

\section{Litteratur}

1. Helsedirektoratet. Regelverk og standardskjemaer for spesialiteten generell kirurgi. https://helsedirektoratet.no/autorisasjonutdanning-og-godkjenning/spesialistgodkjenning/ lege/generell-kirurgi (4.1.2016).

2. Den norske legeforening. Kurskatalogen. Basic surgical skills course. http://legeforeningen.no/ Community/kurskatalogen/Kurs/ ?coursenumber=30620 (5.1.2016).

Mottatt 16.12. 2015 og godkjent 18.1.2016. Redaktør: Kaveh Rashidi.

Publisert først på nett. 